\title{
Auditor skills, traits and knowledge evidence from Tunisia
}

\author{
Imen Thabet * \\ PhD in Accounting, Laboratory of Governance Finance Accounting, Faculty of Economics and Management, University of Sfax \\ *Corresponding author E-mail: thabet_imen@yahoo.fr
}

\begin{abstract}
Several researches have sought an understanding of personal and psychological characteristics contributing to auditor expertise in decision making. The motivation for this study is issued from the need to improve understanding of auditor skills and characteristics in the step of the expression of professional judgment.

This paper aims to looking for and to understand auditors' skills, traits and knowledge contributing to business risk assessment ability. A survey questionnaire is used as a stimulus to gather data from practicing auditors listed on the Roll of the Tunisian Chartered Accountants Order (in 2012). Firstly, survey participants are asked to cite skills and abilities that they consider as important in the step of risk assessment and next to rate the importance of 20 skills using the Likert-type scale.

The results reveal two groups of skills, traits and knowledge which are classified as the most important. The first group gathers three technical skills: Subspecialty Knowledge, Academic Training and World Knowledge. The second group clusters four cognitive skills: Ability to know what is relevant, Decision making ability, Problem solving ability and Assuming responsibility.

This study may be a benchmark for future researches which attempt to increase the understanding of the composition of skills, traits and knowledge associated with technical, behavioral and cognitive attributes which are necessary to assess auditee business risk.
\end{abstract}

Keywords: Business Risk Assessment; Cognitive Skills; External Audit; Technical Skills.

\section{Introduction}

Several companies and organizations are required to have their financial reports checked by an external auditor. To perform audit tasks, the professional needs to be an expert accountant. In fact, he should be able to review the financial statements in order to making sure that they are a time and fair view of an organization's past financial performance and current financial position. In addition, the auditor may offer a range of services. This includes checking that organizations are meeting legal and voluntary obligations in such areas as corporate and social responsibility, information technology and general business risks.

The auditor initiates his mandate with understanding the client's business and industry. This task requires the ability to quickly frame a picture of the client's business, the organization and potential risks that can affect the entity. That is, the assessment of the client's business risk represents an important phase of the audit planning process. However this phase is habitually challenging for the professional because some of these auditors often lack competencies which are necessary to perform such assessment. Therefore, the auditor should have exceptional people competencies in order to know how to do some tasks well.

Competence or expertise definition differs according to the author approach and the research field.

In psychology, competence refers to attitudes, features of the personality and knowledge. It consists of the whole of theoretical and practical knowledge, including the cognitive aptitudes. It is an articulation of the knowledge to produce an activity. It is a package of the knowledge, the know-how and the know to be. According to Herbert Simon, expertise is a set of knowledge and abilities to solve problems. It could be seen as a privileged status of human cognitive activity in which the implementation of the knowledge acquired for a competence is done in a natural way and indisputable (Prince, 1991).

In the science of work, Zarifian (1999) defined the competence of individuals in 3 ways. The first stipulates that competence is the attitude of taking initiative and responsibility on the situation which they face, and which they have the load. The second definition covers the competence of the side knowledge that individuals mobilize in their work. According to the third vision, competence is the manner of mobilizing a collective or a working network.

In auditing, according to DeAngelo (1981), auditor competence is the probability to discover a breach in the client's accounting system. This probability depends on different factors. It depends on the auditor's technological capabilities, the audit procedures employed on a given audit, the extent of sampling, and the auditor size and type.

Otherwise, expertise in auditing is the ability to perform a complex semi-structured task in a superior manner based on accumulated domain-specific knowledge (Wright, 1988). It is the ability acquired by practice to perform a particular task well. Bédard (1989) suggested that an expert auditor must possess a large set of knowledge and procedural skills. Another view of expertise examined by Flint (1988) and Bonner \& Lewis (1990) suggested that training and experience create knowledge. This knowledge is then combined with an innate problem-solving ability. Further, Shanteau (1992) proposed that expertise is dependent on five factors: domain knowledge, psychological traits, cognitive skills, decision strategies and task characteristics.

This paper adopts part of a framework derived from the decisionmaking literature in psychology and applies it to auditing. The focus of the study is to looking for the auditors' skills, traits and 
knowledge (further STK) which are necessary to auditors to succeed in the step of assessing auditee business risk (further ABR).

This study contributes to construct a mental model of the external auditor.

The first main part of the paper presents brief descriptions of the Tunisian audit profession, the previous literature, and research questions. The second main section provides a description of the research design. The last part is dedicated to the empirical results analysis. The paper concludes by highlighting its contribution in terms of enhancing theoretical and empirical understanding of the set of STK that are essential to be successful auditors.

\section{Literature review and research questions}

In Tunisia, financial external audit profession (Statutory Audit) was instituted and regulated for the first time by the Law No. 59129 of October 5, 1959 that established the Commercial Code. Until 2002, the Statutory Audit was carried out only by Chartered Accountants that are members of the Tunisian Order of Chartered Accountants (TOCA). Following the enactment of the Law No. 2002-16 of 4 February 2002 on the organization of the accounting profession, financial statements audit was extended to Technicians on Accounting that are members of the Tunisian Company of Accountants (TCA). The profession is stewarded by Laws, Orders and Decrees promulgated by the Ministry of Finance as well as the rules that prescribed by the TOCA, the TCA and the IFAC.

\subsection{An overview of earlier researches}

In order to identify determinants of auditor judgment ability in the stage of ABR assessment, it appears necessary to review earlier researches.

Since the 1990s, researchers have sought to study and identify competencies necessary to successfully function as a professional auditor (Palmer et al., 2004) and thus to better understand auditor expertise factors. They considered the auditor expertise level as a proxy of auditor ability to perform the right judgment during all the audit process.

The first step of the audit process is the planning and the design of the audit. Throughout this phase, the auditor performs four tasks in order to develop an overall audit plan and an audit program. These tasks include preplanning, obtaining background information and information about the client's legal obligations, assessing the desired levels of materiality and associated risks (inherent risk, Business risk) and studying and developing an understanding of the internal control structure and assessing the associated control risk.

This phase is interactive and iterative. It requires a certain level of expertise. In fact, the professional should have the ability to collect information about the client and the external and internal environment, and the capacity to understand the interaction between the auditee and his environment and the ability to estimate associated risks (Abdolmohammadi \& Shanteau, 1992). In the same way, Butt (1988), Libby \& Frederick (1990), Tubbs (1992) and Wright \& Wright (1997) showed that if an auditor is expert, he has a great ability to assess auditee risks and to detect potential financial misstatements.

Bonner \& Lewis (1990), Ashton (1991) and Kent \& al. (2006) studies, amongst others, focused to identify the characteristics of an expert auditor. They emphasized the importance of the experience in the personal expertise development. In addition, Shanteau (1987), Shanteau \& Peters (1989), Libby \& Tan (2001), Nelson \& Tan (2005) and Kent et al. (2006) interested to psychological, cognitive and behavioral traits which can enhance the professional expertise.

Shanteau (1987) suggested that expert decision makers possess 14 psychological characteristics. This set of characteristics could increase the understanding of an individual's decision-making attributes, and thus explaining expertise in auditing. These attributes include: (1) A highly developed perceptual/attention ability;
(2) An ability to spot between relevant and irrelevant information when making decision; (3) An ability to simplify complexities; (4) A strong set of communication skills; (5) A knowledge of when to make exceptions, (6) A strong sense of responsibility for their choices; (7) A selectivity about which problems to solve, (8) An outward confidence in their decisions; (9) An ability to adapt to changing task conditions; (10) A highly developed content knowledge about their area; (11) A greater automaticity of cognitive processes; (12) Ability to tolerate stress; (13) A capability to be creative and (14) An inability to articulate their decision processes.

Later, in 1989, Shanteau \& Peters considered 3 characteristics as the most determinants of audit judgment: Creativity, Confidence and Communication. They found that current knowledge, knowing what's relevant, assuming responsibility and being a perfectionist are the four top characteristics of an expert.

Bonner \& Lewis (1990), in their paper Determinants of Auditor Expertise published in Journal of Accounting Research, examined the roles of various types of knowledge and ability in auditor performance. They considered at least three types of knowledge and one type of ability as potential determinants of expertise in various auditing tasks: (1) general domain knowledge; (2) subspecialty knowledge; (3) world knowledge and (4) general problem-solving ability.

Based on expert attributes developed by Shanteau (1987), Abdolmohammadi \& Shanteau (1992) and Kent et al. (2006) focused on psychological and behavioral characteristics. Abdolmohammadi \& Shanteau (1992) identified 20 of auditor decision quality attributes They found 3 categories of traits. In the top, there are three cognitive characteristics (knowledge, experience and intelligence). The second category includes confidence, decisive, objective, responsive, and communication, which are presentation- style characteristics. The third item reflects strategic attributes (creative, analytical, thinker, common sense, looks at alternatives). Kent et al. (2006) assessed the perceived importance of these characteristics by eliciting practicing auditors' perceptions of the importance of these characteristics in the audit process. Their results showed that each of the 14 Shanteau characteristics is important across all four phases of the audit, but the degree of varies across characteristics and between audit phases. Characteristics perceived to be most important to all phases of the audit are perceptual/attention and relevant and irrelevant information while the least important are the capability to be creative and an inability to articulate decision processes.

In Tan \& Kao (1999) study, three factors have been examined that may moderate the relation between accountability and auditor performance: knowledge, problem-solving ability, and task complexity.

In addition, Nelson \& Tan (2005) used psychological lens to understand, evaluate, and improve judgments, decisions, or choices in an auditing setting. They aimed 4 types of factors that can determine the auditor judgment quality and thereby improve auditor performance: (1) auditor knowledge and expertise, (2) other individual characteristics, (3) cognitive limitations, and (4) decision aids.

Kavanagh \& Drennan (2008) examined perceptions of graduating students about the skills and attributes they consider important to their career and the skills and attributes expected by a diverse group of employers, in the first hand, and explored gaps between student perceptions and employer expectations. Their results showed that students perceive 4 types of skills which are important in their career: (1) personal and communication skills (self motivation, professional attitude, oral and written communication, teamwork and values), (2) analytical / design skills (analytical and problem solving), (3) appreciative skills (decision making and critical thinking), and (4) leadership and interpersonal skills. Their results revealed also that the top three skills required by employers are: (1) analytical / problem solving, (2) business awareness / real life experience, and (3) basic accounting skills. Oral and written communication skills, ethical awareness / professional skills, 
teamwork and whole of business were ranked the next most important skills and attributes.

According to these researches, exhibited above, an auditor who has a set of skills and knowledge (technical, cognitive and behavioral) has more ability to detect and assess client business risks, which is the first step (phase) of the audit process.

Since 1989, Practitioners (Big Eight White Paper, 1989) and the international accounting and auditing organizations (Accounting Education Change Commission - AECC 1990; Institute of Management Accountants - IMA 1994-1996-1999; institute of internal auditors- competency framework of internal auditors - IIA-CFIA 1999; American Institute of Certified Public Accountants AICPA 1999; International Federation of Accountants - IFAC 2003) have sought to identify Accountants competencies. These studies found 8 knowledge, skills and abilities, which considered as important: communication skills, interpersonal skills, general business knowledge, accounting knowledge, problem solving skills, information technology, personal attitudes and capabilities and computer skills (Palmer et al., 2004).

Later, The Canadian Chartered of Accountants Company published in 2012 the chartered professional accountant competency map: understanding the competencies a candidate must demonstrate to become a CPA. This map defines the specific competencies developed during the CPA certification program, including both the professional education program and practical experience component. In addition to the expected proficiency level at point of entry, the CPA competencies map lists two categories of competencies. The first gathers 5 CPA enabling competencies, which are (1) Professional and ethical behavior, (2) Problem-solving and Decision-making, (3) Written and oral communication, (4) Self management, and (5) Teamwork and leadership. The second category includes 6 technical skills, which are (1) Financial reporting, (2) Strategy and governance, (3) Management accounting, (4) Audit and assurance, (5) Finance, and (6) Taxation.

\subsection{Auditor skills, traits and knowledge}

Experience, volume of knowledge, technical skills, and cognitive and psychological qualities of the auditor are so significant in the fulfillment of audit tasks (Shanteau, 1987; Peters \& Shanteau, 1988; Shanteau \& Peters, 1989; Abdolmohammadi \& Shanteau, 1992; Nelson \& Tan, 2005; Kent et al., 2006; Kavanagh \& Drennan, 2008; Armitage \& Poyzer, 2010).

i) Coping

According to Lazarus \& Folkman (1984), Coping is a set of cognitive and behavioral efforts to manage internal or external specific needs that are assessed as specific by testing or exceeding human resources. It is the ability to adapt to various situations and adjust behavior according to the characteristics of the environment, the challenges of the situation, the new conditions, and the type of contact. It is a process consisting of elaborate strategies to try to master the showers situations and / or to reduce distress caused by these situations.

The accounting profession changes require accountants to adapt. They are faced on new information and they are able to give up their old beliefs and change their way of working. They incorporate new parameters of a given situation, and quickly change their behavior if it is necessary.

In auditing, the adaptability and attention allows the professional to collect more useful information to its purpose and to identify the necessary questions he will ask his client. So, he needs to have the ability to deal with all types of clients in all types of client situations.

The auditor adapts its decision strategy in outstanding situation. It reacts to changes and conditions that may jeopardize the going concern assumption (Shanteau \& Peters, 1985; Abdolmohammadi \& Shanteau, 1992; Kent et al., 2006).

ii) Assuming responsibility

The objective of the auditor is to attest, on its own name and under its own responsibility the sincerity and the regularity of the financial statements and the company's management report.
Auditor's decisions cover the client risk assessment, setting the materiality level, the choice of the audit strategy, the choice of audit procedures to set up and the opinion expression, etc.

Therefore, the auditor is required to assume the responsibility of his decision and judgment results (Shanteau \& Peters, 1989; Abdolmohammadi \& Shanteau 1992) since his purpose is to enhance the degree of confidence of intended users in the financial statements.

iii) Creativity

Creative thinking increases the ability to think differently, to solve problems effectively and to find adequate solutions to problems. Being able to think creatively can find solutions to problems that others have failed to find.

The ability to think differently from others and quickly can be a huge benefit. It does not follow a set of predefined rules. It is a 'general' individual process. This process involves four steps. The first step is an analysis step. It consists in taking a little retreat compared to the situation in order to obtain an overall vision and to collect all information in order to be able to ask the right questions. The analysis increases the ability to explain and understand perfectly the situation. The second step is brainstorming. It is in this stage that the creative thinking works. In fact, it is in this stage that the individual starts to reflect, launch ideas and solutions. Once these ideas and solutions are saved, the individual selects the most appropriate and suitable ideas. The last step consists with the final review and selection of the final idea.

The accounting profession requires ability to think and to find the best ideas. The auditor, in particular, is able to find one or more solutions to a new problem. If necessary, he can generate new approaches to solve problems (Shanteau \& Peters, 1989; Abdolmohammadi \& Shanteau, 1992; Kent et al., 2006).

\section{iv) General business knowledge}

Auditor uses knowledge already acquired to make more or less automatic decisions. Its background and its experiment enable him to make decisions without making extra or special efforts (Shanteau \& Peters, 1989; Bonner \& Lewis, 1990; Ashton, 1991; Abdolmohammadi \& Shanteau, 1992; Wright \& Wright, 1997; Kent et al., 2006; Kavanagh \& Drennan, 2008).

Wright (1988) and Bédard (1989) studied how the experience affects the auditor ability to perform audit tasks successfully. Nevertheless, the direct relationship between the experience and the ability to accomplish task effectively isn't significant. In this context, Tubbs (1992) argued that there is an intermediate parameter between the experience and the effectiveness, which is the volume of the knowledge acquired by the auditor following his experience. According to Christ (1993), more the experience increase, more the audit planning reflects structured information cartography. This cartography includes a set of general or global knowledge, knowledge about the association between information, and a specific knowledge about industries and clients.

In addition, the International Standard on Auditing (ISA 315) stipulates that auditor experience and knowledge acquired during previous missions can help the professional in the phase of risk assessment.

\section{v) Academic training}

Prior researches used some expressions to talk about technical and academic competencies of the auditor: General Domain Knowledge (Bonner \& Lewis, 1990); Entry Level Technical Managerial Accounting Knowledge (Stone et al., 2000); Basic accounting skills (Kavanagh \& Drennan, 2008).

This kind of skills is acquired through formal training and through general experience as an auditor. It is a basic level of accounting and auditing knowledge, including knowledge of generally accepted accounting principles, generally accepted auditing standards, and the flow of transactions through an accounting system (Bonner \& Lewis, 1990)

vi) Decision making ability

Decision making can be hard. The auditor makes decisions along all the audit process. The challenging parts are to select the best decision given the information that the auditor has gathered to assist with the decision, and to make these decisions at times. 
In this context, according to Shanteau (1987) and Shanteau \& Peters (1989), the mission of expressing an opinion on the reliability of financial statements and on the overall viability of the entity requires that the auditor be able to make the good decisions rapidly, prioritize actions according to their importance, the nature and severity of the problem which has occurred, and to choose between the good and the bad solution. Tan's (1999) study includes "decisive", referring to making "decisions quickly, clearly and emphatically". According to Nelson and Tan (2005), the audit task includes activities and decisions related to risk assessment, audit planning, evidence evaluation (sufficiency and appropriateness of audit evidence), auditors' decisions regarding whether to require clients to book proposed adjusting journal entries, and going concern judgments. These activities require decision making and judgment on the auditor's part, which highlights the importance of decision-making skills to be effective as an auditor.

vii) Communication skills

According to Shanteau (1987), Shanteau \& Peters (1989), Kent et xiv) al. (2006) and Kavanagh \& Drennan (2008), communication skills mean that Experts can convince others that they have specialized knowledge. They can effectively communicate their ability to make decisions to others (Shanteau \& Peters, 1989).

Communication is the ability to express in verbal or written form, to understand oral or written language, and to interact appropriately. The ability to communicate improves independence, personal and professional life of the individual.

On the one hand, the work team assigned to an audit engagement requires that employees and the head of mission have the capacity to convince the interlocutor of their know-how (Shanteau, 1987; Shanteau \& Peters, 1989; Kent et al., 2006).

On the other hand, clients want to talk to the auditor, and the better the auditor is at effective communication, the better the conversation is with the client. Effective communication occurs when the client understands exactly what client is saying.

\section{viii) Methodical}

Reasoning is an intelligent action in which the individual processes information in order to draw conclusions. It is a method of passing from premises to conclusion under a logical connection. It is a mental activity that requires a high level of reflection activity (comparison, transformation of mental representations) and a lowlevel activity (performed automatically).

In other words, it is a higher level of cognitive process that uses $\mathrm{x}$ data (drawn from pre-existing cognitions or perceptions) to determine a new cognition (new result) or to check the validity of a fact, by applying data transformation laws.

To describe a new problem, the auditor sets out a strategy, an approach and an action plan and proceeds step by step to make decision (Shanteau, 1987; Shanteau \& Peters, 1989; Kent et al., 2006).

\section{ix) Perfectionist}

In psychology, perfectionism is to behave that perfection couldxvi and should be achieved. A "normal" perfectionist withdraws a real feeling of pleasure of the work required through a sustained effort. To feel satisfied, the auditor attempts to achieve high levels of decision making by seeking the best of all possible strategies. He keeps working to find the absolute best solution for the problem (Shanteau, 1987; Shanteau \& Peters, 1989).

\section{$\mathrm{x}$ Self confidence}

The self confidence is one of the most important of character traits to the wellness and the success. Confidence has a psychological aspect dependent on the individual personality. It is a set of expectations and believes. It is a judgment by anticipation.

To achieve his goal, the auditor has a strong belief in his ability to make good decisions. He should be calm and self assured while making decisions (Shanteau, 1987; Shanteau \& Peters, 1989).

\section{xi) Warm and friendly}

A sociable person is someone who feels good in himself, adapts and integrates easily with others, and which keeps his convictions. In some cases, the personnel of auditee have a fear of the auditor because they don't like someone looking over their shoulders. So the auditor must have the ability to put the personnel of his client at ease and be able to empathize from the client perspective. It is also important for the auditor to show respect for the client.

The auditor should get along well with people, even in difficult decision-making tasks. He uses personality to smooth things over and appear more convincing when making decisions (Shanteau \& Peters, 1989).

\section{xii) World knowledge}

General Knowledge or World Knowledge (Bonner \& Lewis, 1990), which is a kind of knowledge acquired through personal experiences and reading, can increase the level of auditor expertise (Bonner \& Lewis, 1990) and performance (Einhorn, 1974). Kavanagh \& Drennan (2008) spoke of knowledge in terms of Real World.

\section{iii) Energetic}

The auditor gives the impression and fact proof of his energy at the time of decision making (Shanteau, 1987; Shanteau \& Peters, 1989; Abdolmohammadi \& Shanteau, 1992).

\section{Ability to know what is relevant}

Based on experience, auditors can readily distinguish relevant from irrelevant information in a problem. They use only what is relevant and ignore what is not (Shanteau, 1987; Shanteau \& Peters, 1989; Abdolmohammadi \& Shanteau, 1992). In addition, the most important expertise characteristic for the first phase of the audit is an awareness of the difference between relevant and irrelevant information (Kent et al., 2006; Armitage, 2008; Armitage \& Poyzer, 2010).

\section{xv) Problem solving ability}

General problem-solving ability includes the ability to recognize relationships, interpret data, and reason analytically (Bonner \& Lewis, 1990). The capacity of problem solving is a fundamental characteristic of an expert auditor (Tan \& Kao, 1999; Wuttke \& Wolf, 2007; Kavanagh \& Drennan, 2008). Indeed, the auditor is able to control the different solving problem methods in order to develop alternatives and to choose the best solution.

\section{xvi) Exceptions making}

The auditor can be in typical situations. These situations require of the auditor a capacity to make exceptions and to deviate of the pre-established approach, and to make the best decision. According to Shanteau \& Peters (1989), an expert auditor knows when to follow established decision strategies and when not to. He has not just one way to solve problems.

\section{Problem selectivity ability}

Selectivity capacity helps the auditor to detect and assess the risks and further to set up the most appropriate and adequate audit procedures.

An expert auditor uses foresight and planning in selecting which problems to work on and which not. He tackles those problems that he can effectively handle or resolve (Shanteau \& Peters, 1989; Kent et al., 2006).

\section{ii) Stress tolerance}

Stress is a "particular transaction between an individual and a situation in which it is assessed to be outside his resources and can damage his well being (Lazarus \& Folkman, 1984). It results on a dynamic relation between an individual and the environment exigencies, individual and social resources and the individual perception of this relation. It is a process by which threatening events cause behavior adjustment (Guillet, 2008). It is a physical and emotional response on pressure.

In auditing, the professional should be able to make decisions under high stress situations. He continues to be effective problem solvers even as conditions progressively worse because of high levels of pressure (Shanteau \& Peters, 1989).

\section{xix) Subspecialty knowledge}

Besides Global Business Knowledge, a second type of experience to be considered is subspecialty knowledge related to specialized industries or clients, acquired by persons who have experience with specific audit clients, with certain industries, and/or firm training in those specialized areas. Such knowledge is less likely to be acquired through general experience. Thus, not all auditors held the same level and type of experience. Subspecialty Knowledge refers to the specialization of the auditor in the audit 
of financial statements of client operating in a specified industry. In fact, according to Choo (1996), repeated exposure to a specific situation may be an alternative proxy of auditor expertise in the evaluation of going concern assumption. In this area, two research streams are conducted.

The first research line focused to study the impact of the auditor specialization on its effectiveness in detecting the financial statements anomalies. Bedard \& Biggs (1991) found that auditors with more experience in the manufacturing sector are better able to identify errors in the accounts of the sector, than less experienced auditors. Similarly, Johnson et al. (1991) found that experience enhances the ability of the auditor to detect fraud. Likewise, the specialization of the auditor increases the ability to detect cases of significant errors (Wright \& Wright, 1997; Bell et al., 1997) and to look at consistencies (Bell et al., 1997). In fact, auditors with knowledge and an understanding of an industry characteristics and operations are more effective than auditors with no knowledge (Maletta \& Wright, 1996).

The second research stream sought to investigate on the effect of the specific experience in a sector of activity on the auditor's ability to appreciate the opportunities and unusual and significant threats. Biggs et al. (1993) found that experienced auditors, against inexperienced ones, are supposed to identify more abnormal events in their assessment of the going concern of their clients. Low (2004) showed, instead, that a good knowledge of a sector affects positively the auditor's ability to assess the audit risk. He found, first, that specialization in an industry (banking) enhances the auditor's ability to assess audit risk and thus influences the nature and the perceived quality of its planning decisions. Second, he found that the specialization of the auditor has a moderating effect on the sensitivity of planning decisions through risk assessment audit.

$\mathrm{xx}$ ) Decision aids support

Using techniques from Artificial Intelligence (Expert System) as decision aid support is expected to increase or replace the skills of decision makers (Daniel \& Watkins, 1989).

At the time of decision making or problem solving, the auditor is based on a pre-established formal support. The decision aid support can be materialized through standards and laws that regulate the audit mission (audit manuals, checklists, and work programs) and the conception of Expert System.

The use of a decision aid support can't be a pricey potential alternative and it can be considered as an external mechanism to overcome the incompetence or non-performance of the auditor (Nelson $\&$ Tan, 2005). Thus, the decision aid support cannot change the individual judgment of the auditor, but it can facilitate decision making in the context of teamwork, (Bamber et al., 1996). Bonner et al. (1996) developed a different approach of developing decision-support materials to fulfill specific human judgment weaknesses.

For some tasks, for example ratios calculating, it is efficient to use the support as a decision tools. But, in the step of the expression of an opinion or advice, human judgment is more effective and more efficient than the use of decision tools support; given that they can reduce the precision, accuracy and consistency of judgment.

However, the extensive use of decision aids may affect the construction of knowledge and therefore the experience for new inexperienced auditors (Glover et al., 1997).

\subsection{Research questions}

The motivation for this study arises from the importance of auditor STK in the step of business risk assessment.

This paper focuses three of Shanteau (1992) expertise factors: the domain knowledge and the psychological and cognitive skills possessed by experts. The 20 characteristics applied to the first audit phase in this study emanate from these factors. It tries to extend prior studies in so far as it is the first research, performed in Tunisia that investigates on the set of auditor knowledge necessary in the phase of client business risk assessment.
Thus, in this paper, we try to resolve the following two question researches:

RQ 1: What are the professional characteristics that auditors perceive as necessary to improve the ability to assess client business risk?

The objective of research question 2 is to develop a set of key competencies based on the list of STKs identified in earlier studies. RQ 2: Which professional STK, among the 20 characteristics, that auditors consider as important in the step of client business risk assessment?

\section{Research design}

\subsection{Survey questionnaire}

A survey questionnaire is used as a stimulus to gather data from practicing auditors listed on the Roll of the Tunisian Chartered Accountants Order (in 2012). The questionnaire was given to a company manager and to a chartered accountant to test for complexity and applicability. Discussion with them led to make some upswings.

The questionnaire consisted of two parts. In the first part, questions were designed to collect auditor characteristics and skills as cited spontaneously by the participants.

Auditors are invited to respond to the question:

In your opinion, what are the qualities that the auditor should have to assess his client Business Risks?

After collecting data, the classification of cited characteristics is based on the result on prior researches and on the number of times that each characteristic is cited.

In the second part of the questionnaire is designed to capture participant's importance ranking for each characteristics, traits and skills. A five-point Likert-type scale $(1=$ 'not at all important', 5 $=$ 'very important') was used. So, a list of 20 STK are proposed to the survey participants.

\subsection{Sample and characteristics of respondents}

The study sample was drawn from the Roll of the Tunisian Chartered Accountants Order. A survey has been conducted from 93 auditors.

We gathered 51 responses to the first research question (with response rate $54.8 \%$ ) and 54 responses to the second research question (with response rate $58.1 \%$ ).

\section{Results}

\subsection{Auditor competencies cited spontaneously}

Survey participants cited 82 characteristics that considered as important in the step of client business risks assessment. These characteristics are gathered into 21 , as illustrated in Table 1. Skills classification is based on the number of times that each quality is cited.

The perusal of the table above shows that the participants cited more technical knowledge rather than other type of skills. The results exhibit that the most cited characteristics is Experience (68.62\% of participants).

In addition, General Knowledge and Specialization are cited by, respectively, $60.78 \%$ and $50.98 \%$ of auditors. According to prior studies these three skills are technical knowledge (Bonner \& Lewis, 1990; Wright \& Wright, 1997; Stone et al., 2000; Low, 2004).

Table 1 shows that Methodical and having a Self Confidence are the most cited psychological traits, $39.21 \%$ of survey participants. These findings are consistent with earlier researches, such as Shanteau (1987), Shanteau \& Peters (1989) and Kent et al. (2006). 
Table 1: Auditor Characteristics Cited Spontaneously Auditor Characteristics

\begin{tabular}{llll}
\hline & Auditor Characteristics & $\mathrm{Nb}$ & $\%$ \\
\hline 1 & Experience & 35 & 68.62 \\
2 & General Knowledge & 31 & 60.78 \\
3 & Specialization & 26 & 50.98 \\
4 & Methodical & 20 & 39.21 \\
5 & Self Confidence & 20 & 39.21 \\
6 & Technical Knowledge & 20 & 39.21 \\
7 & Ability to Know What is Relevant & 16 & 31.37 \\
8 & Objectivity & 16 & 31.37 \\
9 & Communication Skills & 14 & 27.45 \\
10 & Integrity & 12 & 23.53 \\
11 & Strong Personality & 12 & 23.53 \\
& Type of Personality (Tenacity, Perspicacity, Open & & \\
12 & Minded, Easy Integration to the Group, Intelligence, & 12 & 23.53 \\
& Energy, Curious, Creative, Ability to Adapt to Situa- & 11.5 & \\
13 & tions) & & \\
14 & Globendence & 11 & 21.56 \\
15 & Problem Solving Ability & 10 & 19.60 \\
16 & Decision Making Ability & 9 & 17.64 \\
17 & Responsibility & 6 & 11.76 \\
18 & Ability to Listen & 5 & 9.80 \\
19 & Ability to Manage a Work Team & 4 & 7.84 \\
20 & Perfectionist & 4 & 7.84 \\
21 & Autonomy & 2 & 3.92 \\
\hline & & 1 & 1.96 \\
\hline
\end{tabular}

\subsection{Auditor skills classification}

Research question 2 seeks to identify auditors' key competencies among the 20 STK as defined above.

According to importance rating, as illustrated in table 2, two categories of skills could be showed. Each category is divided into 2 sub-categories of skills (very important skills group and important skills group).

The first category includes Technical Skills. Subspecialty Knowledge $(66.7 \%)$, Academic Training $(50 \%)$ and World Knowledge (42.6\%) are considered as very important skills. These results are consistent with these founded in prior studies (Bonner \& Lewis, 1990; Christ, 1993; Bedard \& Bigg, 1991; Johnson et al. 1991; Choo, 1996; Wright \& Wright, 1997; Bell et al., 1997; Low, 2004; Kent et al., 2006).

General Business Knowledge and Decision Aid Support are ranked as important respectively by $46.3 \%$ and $31.5 \%$ of auditors The importance of General Business Knowledge was not confirmed in Bonner \& Lewis (1990) study, but, confirmed by Christ (1993).

Table 2: Auditor Characteristics Classification

\begin{tabular}{|c|c|c|c|c|c|c|}
\hline \multicolumn{2}{|c|}{$\begin{array}{l}\text { Auditor } \\
\text { Characteristics }\end{array}$} & \multirow{2}{*}{$\begin{array}{l}1 \\
1.9\end{array}$} & \multirow{2}{*}{$\begin{array}{l}2 \\
24.1\end{array}$} & \multirow{2}{*}{$\frac{3}{37}$} & \multirow{2}{*}{$\begin{array}{l}4 \\
16.7\end{array}$} & \multirow{2}{*}{$\begin{array}{l}5 \\
20.4\end{array}$} \\
\hline 1 & Coping & & & & & \\
\hline 2 & Assuming responsibility & 14.8 & 18.5 & 16.7 & 24.1 & 25.9 \\
\hline 3 & Creativity & & 3.7 & 38.9 & 51.9 & 5.6 \\
\hline 4 & $\begin{array}{ll}\text { General } & \text { Business } \\
\text { Knowledge } & \end{array}$ & & 5.6 & 16.7 & 46.3 & 31.5 \\
\hline 5 & Academic Training & & 7.4 & 13 & 29.6 & 50 \\
\hline 6 & $\begin{array}{l}\text { Decision Making Abil- } \\
\text { ity }\end{array}$ & 7.4 & 9.3 & 11.1 & 42.6 & 29.6 \\
\hline 7 & Communication Skills & 7.4 & 22.2 & 38.9 & 25.9 & 5.6 \\
\hline 8 & Methodical & & 9.3 & 22.2 & 42.6 & 25.9 \\
\hline 9 & Perfectionist & 3.7 & 35.2 & 24.1 & 16.7 & 20.4 \\
\hline 10 & Self Confidence & 7.4 & 25.9 & 29.6 & 22.2 & 14.8 \\
\hline 11 & Warm and Friendly & 16.7 & 20.4 & 22.2 & 33.3 & 7.4 \\
\hline 12 & World Knowledge & 1.9 & 5.6 & 9.3 & 40.7 & 42.6 \\
\hline 13 & Energetic & 20.4 & 37 & 29.6 & 13 & \\
\hline 14 & $\begin{array}{l}\text { Ability to know what is } \\
\text { Relevant }\end{array}$ & & & 22.2 & 44.4 & 33.3 \\
\hline 15 & Problem Solving Ability & 9.3 & & 16.7 & 48.1 & 25.9 \\
\hline 16 & Exceptions Making & & 25.9 & 42.6 & 22.2 & 9.3 \\
\hline 17 & $\begin{array}{l}\text { Problem Selectivity } \\
\text { Ability }\end{array}$ & 3.7 & 13 & 40.7 & 35.2 & 7.4 \\
\hline 18 & Stress Tolerance & 7.4 & 44.4 & 7.4 & 14.8 & 25.9 \\
\hline 19 & $\begin{array}{l}\text { Subspecialty } \\
\text { Knowledge }\end{array}$ & & & 1.9 & 31.5 & 66.7 \\
\hline 20 & Decision Aid Support & 9.3 & 5.6 & 46.3 & 31.5 & 7.4 \\
\hline
\end{tabular}

The second category of skills refers to auditor psychological and cognitive traits which are necessary to perform client business risk assessment. Ability to know what is relevant (33.3\%), Decision making ability (29.6\%), Problem solving ability (25.9\%) and Assuming responsibility $(25.9 \%)$ are the most important psychological skills. These results are consistent with these founded by Bonner \& Lewis (1990) and Kent et al. (2006). In fact, the Ability to know what is relevant can direct the auditor to risks zone in financial statements. It can, also, help him in the verification of going concern assumption of the client.

As shown by Kent et al. (2006), Table 2 reveals three categories' skills. Creativity, Being Methodical, Warm and Friendly are considered as important. Coping, Ability to make exceptions and Self Confidence are classified as moderately important. Characteristics which deal with professional personality (Perfectionist, Energetic, Stress Tolerance) are not significant and haven't an influence on the assessment of business risk.

Table 3: Participants' Mean Importance Ratings of Auditor STK

\begin{tabular}{|c|c|c|c|c|c|c|c|}
\hline \multicolumn{2}{|c|}{ Auditor Characteristics } & \multirow{2}{*}{$\frac{\mathrm{N}}{54}$} & \multirow{2}{*}{$\frac{\text { Range }}{4}$} & \multirow{2}{*}{$\frac{\text { Min }}{1}$} & \multirow{2}{*}{$\frac{\operatorname{Max}}{5}$} & \multirow{2}{*}{$\begin{array}{l}\text { Mean } \\
3.3\end{array}$} & \multirow{2}{*}{$\begin{array}{l}\text { Var } \\
1.231\end{array}$} \\
\hline 1 & Coping & & & & & & \\
\hline 2 & $\begin{array}{l}\text { Assuming respon- } \\
\text { sibility }\end{array}$ & 54 & 4 & 1 & 5 & 3.28 & 2.016 \\
\hline 3 & Creativity & 54 & 3 & 2 & 5 & 3.59 & .435 \\
\hline 4 & $\begin{array}{l}\text { General Business } \\
\text { Knowledge }\end{array}$ & 54 & 3 & 2 & 5 & 4.04 & 716 \\
\hline 5 & $\begin{array}{l}\text { Academic Train- } \\
\text { ing }\end{array}$ & 54 & 3 & 2 & 5 & 4.22 & .893 \\
\hline 6 & $\begin{array}{l}\text { Decision Making } \\
\text { Ability }\end{array}$ & 54 & 4 & 1 & 5 & 3.78 & 1.421 \\
\hline 7 & $\begin{array}{l}\text { Communication } \\
\text { Skills }\end{array}$ & 54 & 4 & 1 & 5 & 3 & 1.019 \\
\hline 8 & Methodical & 54 & 3 & 2 & 5 & 3.85 & .846 \\
\hline 9 & Perfectionist & 54 & 4 & 1 & 5 & 3.15 & 1.487 \\
\hline 10 & Self Confidence & 54 & 4 & 1 & 5 & 3.11 & 1.384 \\
\hline 11 & $\begin{array}{l}\text { Warm and Friend- } \\
\text { ly }\end{array}$ & 54 & 4 & 1 & 5 & 2.94 & 1.525 \\
\hline 12 & World Knowledge & 54 & 4 & 1 & 5 & 4.17 & .896 \\
\hline 13 & Energetic & 54 & 3 & 1 & 4 & 2.35 & 912 \\
\hline 14 & $\begin{array}{l}\text { Ability to know } \\
\text { what is Relevant }\end{array}$ & 54 & 2 & 3 & 5 & 4.11 & .553 \\
\hline 15 & $\begin{array}{l}\text { Problem Solving } \\
\text { Ability }\end{array}$ & 54 & 4 & 1 & 5 & 3.81 & 1.248 \\
\hline 16 & $\begin{array}{l}\text { Exceptions Mak- } \\
\text { ing }\end{array}$ & 54 & 3 & 2 & 5 & 3.15 & .846 \\
\hline 17 & $\begin{array}{l}\text { Problem Selectivi- } \\
\text { ty Ability }\end{array}$ & 54 & 4 & 1 & 5 & 3.3 & .854 \\
\hline 18 & Stress Tolerance & 54 & 4 & 1 & 5 & 3.07 & 1.957 \\
\hline 19 & $\begin{array}{l}\text { Subspecialty } \\
\text { Knowledge }\end{array}$ & 54 & 2 & 3 & 5 & 4.65 & .270 \\
\hline 20 & $\begin{array}{l}\text { Decision Aid } \\
\text { Support }\end{array}$ & 54 & 4 & 1 & 5 & 3.22 & 1.006 \\
\hline Val & d N (listwise) & 54 & & & & & \\
\hline
\end{tabular}

The mean importance rating of each STK as well as its importance ranking is shown in Table 3. The mean importance ratings for all STKs are above the mid-point (with 18 STK having a mean rating above 3.00).

Five STK have a mean rating above 4.00. In fact, Subspecialty Knowledge is the most important STK with a mean importance rating of 4.65 (variance 0.270). Bedard \& Biggs (1991), Johnson et al. (1991), Bell et al. (1997), Maletta \& Wright (1996) and Low (2004) found that a good knowledge of a specific sectors enhance the auditor expertise.

Academic Training is ranked by our participants as the second most important STK (with 4.22 as a mean importance rating and 0.893 as a variance). Prior accountant competency studies have examined the importance basic accounting knowledge, technical knowledge, auditing knowledge and general domain skills. In our study, Academic training is a part of technical knowledge, but it includes basic accounting, auditing, finance, strategy and governance, and taxation knowledge. As a result, we cannot compare our findings with those of prior researches.

World Knowledge takes the thirst most important STK. Our survey participants think that personal experiences and reading com- 
plement Academic Training to fulfill well business risk assessment task. These results are consistent with prior studies results (Bonner \& Lewis, 1990; Kavanagh \& Drennan, 2008).

The ability to know what is relevant is the next most important STK. The possible reason why this characteristic is important to the first phase of the audit is that the auditor needs to be able to differentiate between relevant and irrelevant information to assist in concentrating their efforts on what is important to the audit plan (Kent et al., 2006). Accordingly, Armitage (2008) and Armitage \& Poyzer (2010) highlighted the importance of assessing audit evidence.

General Business Knowledge is ranked the fifth most important STK in our survey with 4.04 as a mean importance rating. Yet the importance of this competency varies depending on studies. Wright (1988), Bedard (1989) and Tubbs (1992) showed that the General Business Knowledge is important to perform audit tasks successfully. Out of the 20 attributes examined by Tan (1999), client knowledge is ranked as the 15th in importance for audit assistants, first for audit seniors, seventh for audit managers, and third for audit partners. Its average importance rank across all organizational levels is ninth out of 20.

Another important finding in our study is that cognitive traits and skills are among the important STK (with mean importance rating above 3.00 and variance $<0.00$ ). To be methodical, creative, to be able to select which problem to solve and to make exceptions are important to the first phase of the audit. According to the findings of Kent et al. (2006), being selective allows the auditor to assess what risks exist and determine the appropriate response. In addition, the ability to make exceptions, to be creative and methodical allows the auditor to develop an efficient and effective audit plan. Table 4 indicates that Communication ability is not among the most important STK. This result is not consistent with the findings of prior studies (Shanteau, 1987; Shanteau \& Peters, 1989; Kent et al., 2006; Kavanagh \& Drennan, 2008). They argued that the ability to communicate improves independence, personal and professional life of the auditor.

\section{Conclusion}

This study seeks to contribute to the extant auditing literature by examining a broader and more comprehensive set of skills, traits and knowledge contributing to auditor expertise.

The aim of this study is to identify auditor STK necessary in the step of auditee business risk. To achieve this objective, two question researches should be resolved.

RQ 1: What are the professional characteristics that auditors perceive as necessary to improve the ability to assess client business risk?

RQ 2: Which professional STK, among the 20 characteristics, that auditors consider as important in the step of client business risk assessment?

The study findings showed that the auditor assessment of business risk ability depends on knowledge and cognitive and behavioral traits. Some of the knowledge areas are acquired in general business and academic training. These knowledge types received high importance ratings.

The results of this research are useful for practitioners involved in audit training and audit personnel selection. Understanding more about inherent personality characteristics, perceived by auditors to be important at the risk assessment phase, could potentially lead to improved training and selection of auditors (Kent et al., 2006). Some characteristics such as: general business knowledge; world knowledge; differentiating between relevant and irrelevant information; and making exceptions; can be acquired through training. Other characteristics such as: self confidence cannot be acquired through training. It is recognized that 'not all novices can learn to become experts' (Bédard \& Chi, 1993). Some people possess an 'innate ability' or certain 'inherent characteristics', that when combined with other factors, such as training, elevate them to the level of experts (Kent et al., 2006).
The result of this study must be interpreted with respect a number of limitations. Firstly, the sample is small and it cannot represent the auditor population. So, there is a problem of generalization of results.

Secondly, the data analysis is descriptive; so, a regression could provide a mental model of an expert auditor.

\section{References}

[1] Abdolmohammadi, M. J, Searfoss, D. G and Shanteau, J (2004): "An Investigation of the Attributes of Top Industry Audit Specialties", Behavioral Research in Accounting, Vol.16, pp. 1-17. https://doi.org/10.2308/bria.2004.16.1.1.

[2] Abdolmohammadi, M.J. \& Shanteau, J. (1992): "Personal attributes of expert auditors". Organizational Behavior and Human Decision Processes, Vol. 53, pp 158-172. https://doi.org/10.1016/07495978(92)90060-K

[3] Armitage, J and Poyzer, J. K (2010): “Academicians' and practitioners' views on the importance of the topical content in the first auditing course", American Journal of Business Education, Vol. 3, No. 1, pp 71-81. https://doi.org/10.19030/ajbe.v3i1.375.

[4] Armitage, J (2008). Changes in the importance of topics in auditing education: 2000-2005. Managerial Auditing Journal, Vol. 23 Iss: 9 , pp.935 - 959. https://doi.org/10.1108/02686900810908463.

[5] Ashton, A.H. (1991). Experience and error frequency knowledge as potential determinants of audit expertise. The Accounting Review, 66 (2), 216-238

[6] Bamber, E. M., Watson, R. T., \& Callahan-Hill, M. (1996). The effects of group support system technology on audit group decision making. Auditing: A Journal of Practice \& Theory, Vol. 15, (spring), pp. 122-134.

[7] Bédard, J \& Biggs, S. F. (1991). Pattern recognition, hypotheses generation, and auditor performance in an analytical task. The Accounting Review 66 (July): 622-642.

[8] Bédard, J. \& Chi, M. T. H. (1993). Expertise in auditing. Auditing: A journal of practice and theory, Vol. 11, (Supplement), pp. 1-32.

[9] Bedard, J. (1989). Expertise in auditing, myth or reality? Accounting organizations and society, $\mathrm{Vol} 14, \mathrm{n}^{\circ} 1 / 2$, pp $113-131$ https://doi.org/10.1016/0361-3682(89)90037-8.

[10] Bell, T B., Marrs, F.O., Solomon, I. \& Thomas, H. (1997). Auditing organizations through a Strategic-Systems Lens. KPMG Business Measurement Process.

[11] Bell, T. B., Peecher, M. \& Solomon, I. (2002). The StrategicSystems Approach to Auditing. In: Cases in Strategic- Systems Auditing. Edited by T. Bell and I. Solomon. KPMG LLP, 1-34.

[12] Bell, T., Lansman, W. \& Schakelford, D. (2001). Auditors' Perceived Business Risk and Audit Fees: Analysis and Evidence. Journal of Accounting Research, 39, 35-43. https://doi.org/10.1111/1475-679X.00002.

[13] Biggs, S. F., Selfridge, M. \& Krupka, G. (1993). A computational model of auditor nowledge and reasoning processes in the going concern judgment. Auditing: A Journal of Practice \& Theory 12 (Supplement): 82-99.

[14] Bonner, S. E. \& Lewis, B. L. (1990). Determinants of Auditor Expertise. Journal of Accounting Research, 28, supplement, 1-20. https://doi.org/10.2307/2491243.

[15] Bonner, S.E., Libby, R. \& Nelson, M.W. (1996). Using decision aids to improve auditors' conditional probability judgments. The Accounting Review, 71 (2), 221-240.

[16] Bouaziz, F. (2008). Les compétences comportementales dans les missions de commissariat aux comptes : Identification et développement. Mémoire pour l'obtention du diplôme national d'expert comptable, Faculté des Sciences Économiques et de Gestion de Sfax.

[17] Bruchon-Schweitzer, M. (2001). Concepts, Stress, Coping: Le coping et les stratégies d'ajustement face au stress, Recherche en Soins Infirmiers, 67, 68-83.

[18] Burland, A. \& Zarlowski, P. (2003). Crise de confiance et normalisation : Entretien avec René Ricol. Revue Française de Gestion, 29 (147), 145-148. https://doi.org/10.3166/rfg.147.145-148.

[19] Butt, J.L. (1988). Frequency judgments in an auditing-related task. Journal of Accounting Research, 26 (2), 315-330. https://doi.org/10.2307/2491106.

[20] Carpenter, T.D. \& Reimers, J.L. (2013). Professional skepticism: The effects of a partner's influence and the level of fraud indicators on auditors' fraud judgments and actions. Behavioral Research in Accounting, 25 (2), 45-69. https://doi.org/10.2308/bria-50468. 
[21] Chartered Professional Accountants - CPA (2012). The chartered professional accountant competency map: understanding the competencies a candidate must demonstrate to become a CPA

[22] Choo, F. (1996). Auditors' knowledge content and judgment performance: A cognitive script approach. Accounting Organizations and Society, 2 (4), 339-359. https://doi.org/10.1016/03613682(95)00048-8

[23] Christ, M.Y. (1993). Evidence of the Nature of Audit Planning Problem Representations: An Examination of Auditor Free Recalls. The Accounting Review, 68 (2), 304-322.

[24] Committee of Sponsoring Organizations of the Treadway Commission-COSO (2013). Internal Control-Integrated FrameworkExecutive Summary, http://www.coso.org/documents/990025P_Executive_Summary_fin al_may20_e.pdf

[25] Daniel, E. O'L. \& Watkins, P.R. (1989). Review of expert systems in auditing, Expert Systems Review, spring - summer, 3-22.

[26] De Angelo, L.E. (1981). Auditor size and audit quality. Journal of Accounting and Economics, 3, 183-199. https://doi.org/10.1016/0165-4101(81)90002-1.

[27] DeBeedle, I., Gonthier.-Becasier, N., \& Mikol, A. (2003). Le développement des grands cabinets anglo-saxons d'audit en France. 24ème Congrès de l'AFC. Belgique.

[28] Diaz M.C. \& Wolfe C., (2008), Auditor Evaluation of Business Risks, American Accounting Association Auditing Midyear Conference, Austin, Texas

[29] Docy, L. \& Kurta, J. (2011). Correspondence analysis applied to psychological research. Tutorials in quantitative methods for psychology, vol 7, $\mathrm{n}^{\circ} 1$, pp 5-14.

[30] Dupray, A. \& Hanchane, S. (2001). Les effets de la formation continue en entreprise sur la mobilité et le salaire des jeunes. Formation Emploi, Dossier $\mathrm{n}^{\circ} \mathrm{73}, \quad 53-73$ https://doi.org/10.3406/forem.2001.2407.

[31] Einhorn, H. (1974). Expert judgment: Some necessary conditions and an example. Journal of Applied Psychology, 59, 562-571. https://doi.org/10.1037/h0037164.

[32] Famery, S. (2005). Avoir confiance en soi. Nouvelle Edition, Paris, 159 pages.

[33] Flint, C., Fraser I.A.M. \& Hatherly D. J. (2008). Business Risk Auditing: A Regressive Evolution?-A Research Note. Accounting Forum, 32, .143-147. https://doi.org/10.1016/j.accfor.2007.12.001.

[34] Glover, S. M., Prawitt, D. F. \& Spilker. B. C. (1997). The influence of decision aids on user behavior: Implications for knowledge acquisition and inappropriate reliance. Organizational Behavior and Human Decision Processes, Vol. 72 (2), pp. 232-255. https://doi.org/10.1006/obhd.1997.2735.

[35] Guillet L. (2008), Stress, Modèles et Application, Communication au XIV Colloque National de la Recherche dans les IUT CNRIUT, 29-30 mai- Lyon

[36] International Federation of Accountants - IFAC (2012). Handbook of International Auditing, Assurance, and Ethics Pronouncements. Edition 2013.

[37] International Federation of Accountants, IFAC (2006), Handbook of International Auditing, Assurance, and Ethics Pronouncements 2007 Edition.

[38] International Federation of Accountants, IFAC (2012), Handbook of International Auditing, Assurance, and Ethics Pronouncements 2013 Edition.

[39] Johnson, P., Jamal, K. \& Berryman, R. (1991). Effects of framing on auditor decisions. Organizational Behavior and Human Decision Processes 50: 75-105 https://doi.org/10.1016/07495978(91)90035-R

[40] Johnstone K. M. \& Bedard J. C. (2004). Audit Firm Portfolio Management Decisions. Journal of Accounting Research, Volume 42, Issue 4, pages 659-690, September 2004 https://doi.org/10.1111/j.1475-679X.2004.00153.x.

[41] Johnstone K.M. (2000). Client-Acceptance Decisions: Simultaneous Effects of Client Business Risk Audit, Auditor Business Risk, and Risk Adaptation. Auditing: A Journal of Practice and Theory, Vol 19, $\mathrm{N}^{\circ}$ 1, pp1-24 https://doi.org/10.2308/aud.2000.19.1.1.

[42] Joyce E.J. \& Biddle G.C. (1981 a), Anchoring and Adjustment in Probabilistic Inference. Auditing, Journal of Accounting Research, Vol 19, nº 1, pp 120-145. https://doi.org/10.2307/2490965.

[43] Joyce, E.J. \& Biddle, G.C. (1981 b). Are Auditors' Judgments Sufficiently Regressive? Journal of Accounting Research, 19(2), 323 349. https://doi.org/10.2307/2490868.

[44] Joyce, E.J., (1976). Expert Judgment in Audit Program Planning. Journal of Accounting Research, 14, 29-60. https://doi.org/10.2307/2490445.
[45] Kavanagh, M H \& Drennan L (2008). What skills and attributes does an accounting graduate need? Evidence from student perceptions and employer expectations. Accounting and finance, Vol 48, issue 2, pp 279-300. https://doi.org/10.1111/j.1467629X.2007.00245.X.

[46] Kent, P., Munro, L. \& Gambling, T. (2006). Psychological Characteristics Contributing to Expertise in Audit Judgment. International Journal of Auditing, $10 \quad$ (2), 125-141. https://doi.org/10.1111/j.1099-1123.2006.00346.x.

[47] Lavergne, J-P. (1983). La décision : Psychologie et méthodologie. Les éditions E.S.F., Paris

[48] Lazarus, R. S., \& Folkman, S. (1984). Stress, appraisal, and coping. New York: Springer.

[49] Libby, R. \& Frederick, D. M. (1990). Experience and the ability to explain audit findings. Journal of accounting research, Vol. 28, pp. 348-367. https://doi.org/10.2307/2491154.

[50] Libby, R. \& Tan, H-T. (1994). Modeling the Determinants of Audit Expertise. Accounting, Organizations and Society, 19 (8), 701-816. https://doi.org/10.1016/0361-3682(94)90030-2.

[51] Low K-Y. (2004). the Effects of Industry Specialization on Audit Risk Assessments and Audit-Planning Decisions. The Accounting Review, Vol. 79, No. 1, pp. 201-219. https://doi.org/10.2308/accr.2004.79.1.201.

[52] Maletta M. \& Wright. A. (1996), Audit Evidence: An Examination of Industry Error Characteristics. Auditing: A Journal of Practice and Theory. Vol. 15, No. 1, pp. 71-87.

[53] Marchant, G. (1990). Discussion of Determinants of Auditor Expertise. Journal of Accounting Research, 28, supplement, 21-28. https://doi.org/10.2307/2491244

[54] Mishara, B. L., Le Concept d'Adaptation (Coping), Directeur du Centre de Recherche et d'Intervention sur le Suicide et l'Euthanasie (CRISE), Professeur, Département de Psychologie, Université du Québec à Montréal. http://www.zippy.uqam.ca/documents/description/concept_adaptati on.pdf

[55] Nelson, M. \& Tan, H.T. (2005). Judgment and Decision Making Research in Auditing: A Task, Person, and Interpersonal Interaction Perspective. Auditing: A Journal of Practice and Theory, 24, Supplement, 41-71. https://doi.org/10.2308/aud.2005.24.s-1.41.

[56] Palmer, K. N., Ziegenfuss, D. E. \& Pinsker, R. E. (2004). International knowledge, skills, and abilities of auditors / accountants- Evidence from recent competency studies. Managerial auditing jour$\begin{array}{llllll}\text { nal, } & \text { Vol. } & 19 & \mathrm{~N}^{\circ} 7, & \text { pp. } & 889-896\end{array}$ https://doi.org/10.1108/02686900410549411.

[57] Pierce, B. \& Kilcommis M., (1996), The Audit Expectation Gap : The Role of Auditing Education, Dublin City University Business School Research Papers, 1995-1996, n 13.

[58] Prince, V. (1991). Expertise naturelle, Expertise artificielle, Vers quels paradigmes cognitifs? Intellectica, 2 (12), 7-31. Richard, C. \& Reix, R. (2002). Contribution à l'analyse de la qualité du processus d'audit: Le rôle de la relation entre le directeur financier et le commissaire aux comptes. Comptabilité Contrôle Audit, 8 (1), 151174.

[59] Shanteau, J. \& Peters, J.M. (1989). The 3 C's of Expert Audit Judgment: Creativity, Confidence, and Communication. Audit Judgment Symposium, CA: University of southern California.

[60] Shanteau, J. (1987). Psychological characteristics of expert decision makers. In J.L. Mumpower, O. Renn, L.D. Phillips, \& V.R.R. Uppuluri (eds.), Expert judgment and expert systems. Berlin: SpringerVerlag, pp. 289-304. https://doi.org/10.1007/978-3-642-866791 16.

[61] Stone, D., Hunton, J. \& Wier, B. (2000). Succeeding in Managerial Accounting, Part I: Knowledge, Ability, and Rank. Accounting, Organization and Society, 25, 697-715 https://doi.org/10.1016/S0361-3682(99)00063-X.

[62] Tan, H-T. (2001). Methodological Issues in Measuring Knowledge Effects. International Journal of Auditing, Vol. 5, pp. 215-224. https://doi.org/10.1111/1099-1123.00337.

[63] Tan, H-T \& Kao, A. (1999), Accountability effects on auditors' performance: The influence of knowledge, problem solving ability, and task complexity. Journal of Accounting Research, vol 37, $\mathrm{n}^{\circ} 1$, pp 209-223. https://doi.org/10.2307/2491404.

[64] The Chartered Professional Accountant - CPA (2012). The Chartered Professional Accountant Competency map: Understanding the competencies a candidate must demonstrate to become a CPA. $\mathrm{Li}$ brary and Archives Canada Cataloguing in Publication.

[65] Tubbs, R.M. (1992). The Effect of Experience on the Auditor's Organization and Amount of Knowledge. The Accounting Review, 67 (4), pp 783-801. 
[66] Vaassen E.H.J., (1994), Auditors' Decision Processes in Audit Planning Stage: Materiality Judgments, Thèse de Doctorat, Faculty of Economics and Business Administration, University of Limburg.

[67] Wright, A. \& Wright, S. (1997). The Effect of Industry Experience on Hypothesis Generation and Audit Planning Decisions, Behav ioral Research In Accounting, Vol 9, pp. 273-294. https://doi.org/10.2139/ssrn.42913.

[68] Wright, W. F. (1988). Audit judgment experience and consensus, in Ferris, K. R. (ed.), Behavioral Accounting Research: A Critical Analysis, Columbus, OH: Century VII Publishing Company, pp. 305-328.

[69] Wuttke, E. \& Wolf, K.D. (2007). Développement d'un instrument permettant d'évaluer la capacité à résoudre des problèmes : Résultats d'une étude pilote. Revue Européenne de Formation Professionnelle, Vol. 41, N², pp. 95-115.

[70] Zarifian, P. (1999). Sur la compétence. Interview with Philippe Zarifian to the DRH of the ANPE, november 1999. http://perso.orange.fr/philippe.zarifian/page50.htm. 